\title{
The French Media and the Forging of a Franco-British Alliance in the late 1930s
}

\author{
Daniel Hucker
}

Keywords: France, United Kingdom, Newspapers, Radio, Twentieth Century, War and Society, Edouard Daladier

Dr Daniel Hucker, Assistant Professor, Department of History, University of Nottingham, Lenton Grove, University Park, NG7 2RD 


\title{
The French Media and the Forging of a Franco-British Alliance in the late-1930s
}

\begin{abstract}
$\underline{\text { Abstract }}$
This article explores the interconnections between the media in France and the emergence of a Franco-British alliance on the eve of World War Two, emphasising how newspaper, radio and newsreel coverage helped mould British perceptions of France during the late-1930s. It will argue that British assessments of France, and thus France's potential value as a wartime ally, were influenced greatly by the dominant representations furnished by the media. In 1936, such representations portrayed a polarised France unworthy of British support; by 1939, they depicted a strong and united country of inestimable value to Britain. This transformation was not simply fortuitous; by the late-1930s, French politicians, conscious of the deleterious effect that media representations of a divided France was having on their country's prestige, endeavoured to transform the media from a symptom of decadence and malaise into a weapon of unity and strength.
\end{abstract}

For much of the interwar period Great Britain and France were uneasy allies, their relations marred by mutual suspicion and distrust. In the deteriorating diplomatic climate of the 1930s, France's all-too-frequent changes of government, ideological skirmishes, and industrial unrest further dented British confidence in their old war-time ally. The result was a residual perception of a weak and divided country and, as P. M. H. Bell has noted, France's 1940 defeat confirmed longstanding British suspicions that France was 'rotted from within before the blow fell from without'. ${ }^{1}$ Early French accounts of the interwar period did little to counter these prevailing conclusions, providing instead the foundations of the 'decadence' thesis, ascribing France's defeat to the moral bankruptcy of the entire nation. ${ }^{2}$ Translated into foreign affairs, decadence resulted in French policy becoming rudderless, subservient to what François Bédarida labelled the 'English Governess'. ${ }^{3}$ More recent accounts provide a corrective to this dominant notion of decadence and submissiveness, emphasizing instead 
French assertiveness and strength. ${ }^{4}$ This article will add to this recent trend by showing how, in the latter-1930s, the French used the media to cultivate perceptions overseas (notably in Britain) of a rediscovered unity and confidence.

British perceptions of France were informed heavily by the media, particularly newspapers. The Paris embassy sent frequent reports on the French internal situation based on parliamentary debates, political meetings, informal discussions with key members of Parisian society, as well as more general gossip, rumour, and hearsay. Nevertheless, as John Herman remarks, newspapers 'provided a rich source of the Embassy's information'. ${ }^{5}$ For much of the 1930 s, such reportage reinforced pejorative impressions of a country emasculated by internecine domestic unrest bordering on civil war, illustrated by the street violence of February 1934. Anglo-French relations were soured further by the 1935 Franco-Soviet Pact, whilst the 1936 election of a Popular Front coalition inclusive of Communists further alienated a British elite dominated by anti-Bolshevik Conservatives. Throughout this period, domestic squabbles in France whether violent disturbances between the far-left and far-right or persistent industrial unrest that impeded rearmament - were reported widely in both French and British newspapers. The image conveyed was overwhelmingly negative; writing in 1935, the British journalist Alexander Werth noted that France was 'in ferment'. 6

The accuracy of this predominant image is questionable. Most foreign observers of France - notably newspaper correspondents and overseas diplomats - were based in Paris, and what happened in Paris was not necessarily representative of the country. Manifestations of social unrest and political squabbling are more prevalent in larger towns and cities, especially a nation's capital. This matters because, although the French press was equally divided between national newspapers and provincial titles, 
politicians (both French and foreign) relied greatly on the Paris press to inform their understandings of newspaper opinion and thus French public opinion as a whole (the two often viewed as synonymous). Occasionally, reports from the Paris embassy would include consular reports on provincial newspapers, but it was predominantly those papers published in Paris that were read and cited. ${ }^{7}$ This focus on the Paris press was not without merit. After all, the Paris press often represented a particular political party, interest group or organization, and thus conveyed the views of diverse constituencies of opinion. In addition, it often provided the information, notably international news, which provincial newspapers subsequently repeated. Newspaper content also informed attitudes abroad, and with most foreign diplomats based in the capital, the Paris press would naturally carry more weight. ${ }^{8}$ And finally, as one British embassy official remarked in April 1937, 'it is in Paris that Ministries fall'. 9

Only a handful of provincial papers - including the Petite Gironde (Bordeaux) and the Dépêche du Toulouse - had an independent editorial line on international affairs. Furthermore, within the Paris press, certain journals were relied on more than others. Interestingly, the two most widely-read papers (by quite some distance) rarely featured in British embassy reports or the dossiers of press cuttings kept by French politicians. These were the Petit Parisien and Paris-Soir, the only two papers with circulations exceeding one million. ${ }^{10}$ Another feature of the French press was how it became increasingly centralised, concentrated in the hands of a few wealthy owners resilient enough to survive in an increasingly unprofitable business. ${ }^{11}$ Wealthy businessmen like the perfumer François Coty who purchased Le Figaro in 1922 and also financed the far-right journals Action Française and Le Flambeau. Paris-Soir was owned by the French sugar trust, hence its popular nickname Paris-Sucre. ${ }^{12}$ The concentration of the press affected content as well as ownership. The number of local papers dwindled rapidly, as did the 'presse politique', both usurped by large-circulation dailies that 
augmented their appeal by sacrificing political commentary for more sport, fashion, and other populist features. ${ }^{13}$

Many 'political' journals nonetheless boasted substantial circulations. These included, on the political right, Le Journal $(411,021)$ and Le Matin $(312,597)$, on the left, the communist Humanité $(349,000)$ - the socialist Le Populaire only sold around 157,000 copies - and in the centre, the OEuvre $(236,045)$. A number of regional papers also sold in excess of a quarter of a million copies, including the Petit Gironde and the La Dépêche de Toulouse. ${ }^{14}$ Le Temps was also widely-cited, principally because it was seen as the semiofficial mouthpiece of the Quai d'Orsay (the French foreign ministry). In addition, several prominent and well-connected journalists drew attention to themselves, notably those with a pronounced interest in foreign affairs, including Geneviève Tabouis, André Géraud (Pertinax), Wladimir d'Ormesson, Henri de Kérillis, and prominent journalists on the left, the socialist Léon Blum and the communist Gabriel Péri in particular. The French government retained privileged links with the media, notably via the Havas wire agency, secret government subsidies, and informal contacts with prominent editors and proprietors. Adamthwaite suggests that the government could have used these links to mould French public opinion in support of Prague during the Sudeten crisis, but instead key officials including the Quai d'Orsay's general-secretary, Alexis Léger and the head of its press section, Pierre Comert - 'anaesthetized' opinion in support of the passive appeasement strategy favoured by foreign minister Georges Bonnet. ${ }^{15}$ The French press was a many-headed beast, comprising populist titles owned by wealthy proprietors, journals susceptible to government manipulation, and political papers that volubly and passionately articulated an ideological agenda. As Matt Perry remarks, 'press culture in 1930s France was vibrant, partisan and venal'. ${ }^{16}$ 
Despite this, British officials in Paris relied heavily on press content to inform their despatches. In fairness, few alternative sources existed; opinion polls were in their infancy and not trusted, especially by the French. ${ }^{17}$ Cinema newsreels reached a large audience but were expensive to produce and lacked substantive commentary. Radio news was similarly limited in scope, but the rapid proliferation of radio sets in interwar France ownership increasing from 5,000 at the end of the 1920 s to more than 5 million a decade later - would prove significant. The power of radio and newsreels was soon recognised by politicians, and would be used to considerable effect by Édouard Daladier at the end of the decade. ${ }^{18}$ But in the mid-1930s, newspapers remained the preferred evidential base, hardly surprising given that most British diplomats and politicians belonged to a generation that believed the press to be powerful, even as its status began to diminish. ${ }^{19}$

Within the pages of contemporary French newspapers it is easy to find indications of a weak, divided, even 'decadent' society, helplessly reliant on British support. Prior to the 1936 elections that ushered in the Popular Front, many French journals expressed concern at the social divisions that plagued the nation at a time of growing external peril; one writer in the Catholic paper La Croix even compared the situation to $1914 .^{20}$ The external peril was amplified by Germany's remilitarization of the Rhineland, which generated a neo-pacifist response on the French right ('Surtout pas de guerre') rooted in an ideological hostility towards Communism, both domestic and international. Newspapers thus perpetuated an image of a divided France incapable of opposing Nazi Germany. ${ }^{21}$ These divisions were duly reported to London, although far greater emphasis was placed on a rare area of consensus - the need for a co-ordinated Anglo-French response. Any indication of discord between Paris and London caused consternation; Britain's ambassador in Paris from 1933 to April 1937, Sir George Clerk, noted French alarm at an apparent 'divergence between the French and British points of view'. 22 
The outcome of the 1936 election ensured that the press subsequently prioritized domestic over foreign news, and when the latter did feature notably vis-à-vis the Spanish Civil War - the prevailing message was that Anglo-French co-operation was paramount. Only far-left journals intimated that France could steer a foreign policy course independently of Britain. Charles Corbin, France's ambassador in London (1933-40), noted that the British were similarly convinced that France's 'internal problems' prevented Paris from pursuing a firm and independent policy. ${ }^{23}$ The Berlin correspondent of Le Temps offered a degree of confirmation, telling Sir Eric Phipps, Britain's ambassador to Germany before taking the Paris post in 1937, that Léon Blum's government had no discernible foreign policy: 'Beyond a determination to collaborate with us' reported Phipps, 'he could find nothing concrete'. ${ }^{24}$ It is easy, therefore, to see where the notion of an 'English Governess' came from.

French domestic unrest did much to cement the notion overseas of a 'decadent' nation lacking the moral fibre necessary to withstand the Fascist challenge. After the 1936 election even the moderate French press noted how the outcome caused 'some surprise' in British political circles and spawned headlines like 'Triomphe de Moscou' and 'La France rouge' in Germany. ${ }^{25}$ The Intransigeant urged calm, reminding its readership of the external menace and warning that a civil war would precipitate a foreign one. ${ }^{26}$ Extreme-right journals lamented the 'decomposition' of French parliamentary politics and the pro-Soviet direction of the Popular Front's foreign policy. ${ }^{27}$ But others sought to reduce ideological tensions. Ahead of Bastille Day, right-leaning French war veterans were warned against turning the Champs Elysée into a 'banal battlefield' between patriots and police, as this would only reinforce perceptions of French disorder when the existential threat demanded unity and sang-froid. ${ }^{28}$ Repeated allusions to unrest in the French press, especially rhetoric of 'civil war', undoubtedly reverberated overseas. For British observers, as Herman insists, the emergent picture 
was of a France plagued by political, social and economic weaknesses: 'It would be a truism to state that France was on the brink of civil war with the country almost equally divided between left and right'. ${ }^{29}$

The wave of sit-in strikes that beset the fledgling Popular Front government during the summer of 1936 prompted partisan press commentary in France that subsequently informed British perceptions. Although British embassy staff tapped into other sources of information - personal contacts, consular reports, visiting sites of strike action, attending rallies, scrutinizing parliamentary debates, etc. - newspapers were an ever-present when trying to make sense of a fluid situation. ${ }^{30}$ Hugh Lloyd Thomas, minister at the Paris embassy, tried to resist the 'alarmist exaggerations' in the press, but confessed nevertheless that the situation was dire, especially from the diplomatic perspective. 'One cannot help feeling' he wrote, 'that for the moment at least the French Government as a fighting force has ceased to exist'. ${ }^{31}$ Clerk also acknowledged a reliance on newspapers, noting how his day-to-day reports were 'based on information published in the press and on reports I have received from His Majesty's consular officers'. ${ }^{32}$

Although optimism resurfaced as the 1936 strikes subsided, confidence in France was routinely shaken by the frequent re-emergence of social unrest. As the Radical Deputy, Lucien Lamoureux, recalled, the factory occupations, the Clichy riots in 1937, and the difficulties experienced in hosting the Paris International Exposition that same year, combined to fuel a belief elsewhere in Europe that France 'was in the grip of a sort of revolutionary anarchy'. ${ }^{33}$ Within the Popular Front, the Radical-Socialists grew alarmed at negative British perceptions. Jacques Kayser, one of the Radical's 'Young Turks', remarked how the British were not irreconcilably hostile to the Front Populaire, but insisted nevertheless that a French financial 'recovery' was essential. ${ }^{34}$ Persistent domestic turmoil certainly troubled many in Britain, and for Conservatives in particular the pernicious influence of Communism was sufficient reason to interpret any British commitment to France as a 'liability’. ${ }^{35}$ By early 1937, Corbin noted that British hostility towards a 
continental commitment was no longer confined to conservative or isolationist papers. Even the Morning Post, he observed, traditionally so 'faithfully attached' to the entente, now published editorials criticizing French policy. ${ }^{36}$

That Britain might desert France was a troubling prospect. France's President, Albert Lebrun, told journalists in February 1937 that newspaper content was exploited abroad to attack an apparently unstable and fragmented France; journalists must henceforth do their duty by presenting instead an image of a united, calm, orderly and industrious nation. ${ }^{37}$ Paris was concerned that London might use France's internal unrest as a pretext for pursuing appeasement with Germany at France's expense. Unsurprisingly, any signs of Anglo-French harmony were received warmly. As Phipps (who had replaced Clerk as ambassador in Paris in April 1937) told foreign secretary Anthony Eden in November 1937, news of the impending visit to London of French Premier Camille Chautemps has had a 'reassuring effect ... on the French Government and French public opinion'. ${ }^{38}$ However, although grateful for signs of Anglo-French harmony, the French press was never sycophantic. In early-1938, as the Front populaire began to disintegrate, several newspapers, especially on the left, condemned perceived British meddling in France's internal affairs. ${ }^{39}$

That the British contemplated such meddling demonstrated their frustration at the perpetual instability in Paris. A volatile and vulnerable France was of little assistance to Chamberlain in his pursuit of appeasement. He sought a stable ally providing 'firm and continuous support', but instead found a country riddled with internal unrest and frequently-changing governments. When Chautemps' administration fell in January 1938 an exasperated Chamberlain described French political instability as 'a phenomenon of Nature which we must just accept'. Corbin warned Paris that the British were tiring of France's persistent 'domestic quarrels', no longer viewing it as 
a relatively harmless inconvenience. Yet another French ministry collapsed on 10 March, leaving France without a government when Hitler pulled off the Anschluss. 'France', lamented Chamberlain 'has been caught bathing, and the world looks to us'. 40

Such was the domestic and diplomatic climate confronting Daladier as he formed a new ministry in April 1938. His administration marked a distinct break from the Popular Front, and one of his first moves was to confront the workers by abolishing the 40-hour working week (a central pillar of the Popular Front platform). As workers' unrest intensified in August, Daladier took to the airwaves to urge the French people to overcome their differences and get 'back to work'. ${ }^{41}$ Diplomatically, his government was animated by a desire to disabuse the British of their prevailing perceptions of France. Daladier sought to demonstrate a rediscovered French unity and resilience, encouraged by Winston Churchill who had informed him on 14 April that the time was ripe for such an initiative, but he must 'strike while the iron is hot'. 42 A visit to London by Daladier and Bonnet was quickly arranged, Phipps keen that the British endorse Daladier's fledgling government which was considered a significant improvement on its vacillating and alarmingly pro-Soviet predecessors. 43 This successful visit was followed in July by an equally well-publicised sojourn by the British King and Queen in Paris. The French, remarked Oliver Harvey(private secretary to Lord Halifax, Britain's foreign secretary since Eden's resignation in February 1938), went to extraordinary lengths to make the visit a success, in so doing reminding both the world and the French themselves of their 'ability to make a success of anything they have a mind to', an ability that had been 'forgotten in the recent wave of defeatism'. ${ }^{44}$ The visit afforded France a rare moment of cross-party unity, the majority of the press on the left and right seizing the opportunity to celebrate the closeness of the two democracies. ${ }^{45}$ 
Most early reports from the Paris embassy painted Daladier's administration favourably, at least vis-à-vis domestic politics. Ahead of the French ministers' visit to London, Phipps reported that sections of French opinion were undergoing a period of soul-searching, not as part of a 'process of aimless disintegration' but rather as a consequence of 'the tremendous thrust for national union' which had become the key motif of French politics. Although the slow but steady progress in this direction had given 'friends of France ... legitimate cause for anxiety', Daladier now had a 'golden chance' to make meaningful progress. ${ }^{46}$ This opportunity was made harder by Hitler's designs on the Sudetenland. The ensuing crisis dominated the diplomatic landscape over the summer of 1938, but France was again distracted by internal unrest as the far-left resisted Daladier's reforms. In this context, as Yvon Lacaze has noted, press commentary on the Sudeten crisis concluded that the outcome depended entirely on the degree of Britain's commitment to France. Even as Hitler increased his demands during September, causing unrest and even resistance in some British newspapers, the majority of French journals continued to toe the appeasement line, partly on account of pressure exerted by the Quai d'Orsay. Unsurprisingly, the Munich reprieve was received warmly, Phipps noting how French papers, with few exceptions, were 'lyrical in their praise' for Chamberlain. 47

Daladier himself, however, was less enamoured by the outcome, as demonstrated by his well-documented appraisal of the jubilant Parisian crowds on his return ('les fous sont cons!') and his general comportment in photographs and newsreel footage from the time. The substantial press cuttings in his personal papers reflect a concern that his actions might incur the wrath of the French people. Unlike Chamberlain, who confidently brushed aside press criticism, Daladier was profoundly perturbed by hostile media voices, particularly those emanating from the left. Also unlike his British counterpart, the French premier eschewed hubristic claims of securing peace for a generation. Instead, he used a radio broadcast to urge 
the French people to remain 'united, hardworking and strong', the only possible safeguard of both domestic and world peace. ${ }^{48}$ Bonnet too was fixated by French press coverage, and in conversations with British embassy staff he habitually accused hostile journals of being in the pay of Moscow. Phipps proved receptive to the foreign minister's lamentations, accepting Bonnet's claims that both l'Époque and l'Ordre were backed by Russia, even accusing the latter's director, Émile Buré, of being 'a slave of the Soviets'. ${ }^{49}$

After Munich the French government attempted to augment its control over the media. On 2 November, Daladier told Phipps that he intended to issue a new decree-law to prevent press attacks 'upon foreign statesmen', no doubt encouraged by British anger at persistent attacks on Chamberlain. Daladier, noted Phipps, 'spoke very bitterly ... about the disgraceful attacks in the Communist Humanité and by 'Pertinax [André Géraud] in the Ordre'.

According to Phipps, the same two journals were the only ones that received news of Chamberlain's impending Paris visit with scepticism rather than enthusiasm. 50 The French press was clearly divided along munichois and antimunichois lines, divisions that Phipps attributed principally to ideology. Papers on the right and centre - notably Le Temps, the Jour-Écho de Paris, La République and Le Matin - supported appeasement, whilst the moderateleft and far-left - represented by the Ordre, Le Peuple, 1'OEuvre and l'Humanité - were opposed. 51

Press discussion of Munich subsided, however, as French internal politics returned centre-stage. One reason for the primacy of domestic rather than foreign issues in French newspapers during the autumn was the calling of a General Strike for 30 November, the unions' response to the programme of financial redressement revealed by the new finance minister, Paul Reynaud. To defeat the strike and rally the French people to his side, Daladier once more turned to the microphone. In a radio broadcast coinciding with the twentieth anniversary of the Armistice, the chef de gouvernement stressed his credentials as a war veteran, portraying the brotherhood of the anciens combattants as an exemplar of national unity for the rest of the country to 
emulate. To withstand the external threat, he insisted, France must be morally and materially strong. ${ }^{52}$ There is evidence that Daladier's appeals to the country were working. Within his personal papers is a note that stated simply, 'For peace and French security, it would evidently be preferable to work than to strike. Such is the general opinion of the French people, disgusted by the attitude of the Communists'. ${ }^{53}$ Furthermore, on 28 November, after a well-publicized and highly successful visit to Paris by Chamberlain and Halifax, Daladier's press service noted how Parisian and provincial papers alike bemoaned the 'current social agitation' which could only harm France's position during the ongoing 'international negotiations'. 54

That the General Strike was having a negative impact on British opinion had already been emphasized by Corbin, who warned that France's 'internal strife' was the issue that 'eclipsed all others' in British press coverage. 55 Daladier's use of the radio was proving effective at home, but for British observers this medium was less significant than the printed page. In the build-up to the General Strike, Daladier, Reynaud and Anatole de Monzie (minister for public works) all took to the airwaves urging discipline, and although Phipps acknowledged that these broadcasts enjoyed 'a wide reception among wireless listeners', he regretted that the 'newspapers of the extreme left do not publish them fully, but only give garbled versions'. ${ }^{56}$. Of all the forms of media in operation, British officials still gave primacy to the printed press. In mid-November 1938, the Paris embassy's press attaché, Charles Mendl, had lengthy conversations with two prominent French journalists, André Géraud ('Pertinax') and Geneviève Tabouis. Both suggested that French strength and stability could be regained if Paul Reynaud's programme of financial redressement was successful. ${ }^{57}$ Within the British Foreign Office France appeared to be 'at the parting of the ways': if the Reynaud plan encountered substantial resistance the future remained unclear and possibly dangerous; if met with 'reluctant acquiescence', the future may well see 'a gradual recovery and immediate increased stability'. ${ }^{58}$ 
The outcome of the General Strike was clearly crucial, and Daladier's success in overcoming it with minimal fuss certainly improved France's standing in the eyes of the British. A further opportunity to showcase French vitality soon emerged. On 30 November, Italian deputies began demanding that France cede Tunis, Corsica and Nice to Italy. The nearunanimous response in the French press needed no positive spin from either the Quai d'Orsay or the British embassy. French newspapers of all stripes roundly condemned Mussolini's provocation, reflecting a broader public hostility that was, as Phipps conveyed, amusingly manifested by a group of Sorbonne students marching 'down the Boulevard St. Michel shouting for Sardinia, Sicily, "Venice pour nos amoureuses" and Vesuvius'.59 Italy's actions, recalled Lamoureux, provoked an 'emotion' in France, resulting in numerous demonstrations, rallies, and protests. ${ }^{60}$ This resolve, however, threatened to impede Chamberlain's pursuit of appeasement. News of Chamberlain's intended trip to Rome in January, coupled with an editorial in The Times on 17 December advocating a frank discussion of Italy's territorial grievances, prompted alarm in France. Wladimir d'Ormesson wrote to a British correspondent that France was 'absolutely unanimous' in its desire to stand firm against the Italians, and that any attempt on Chamberlain's part to mediate would be ill-received. ${ }^{61}$

If Daladier had, as Benjamin Martin claims, received 'a gift from Mussolini' courtesy of the latter's ill-judged demands, ${ }^{62}$ he played his hand adroitly. Firstly, the claims fostered a spirit of French unity that was used to denigrate those on the left espousing social and industrial agitation. Secondly, they provided an opportunity to indulge in a celebration of French imperial grandeur. Where previously a perception of imperial decay was used to legitimize appeasement in Europe ${ }^{63}$, the imperial theme was used after Munich as a symbol of strength rather than weakness. ${ }^{64}$ The use of newsreels to project France's imperial prestige demonstrated the government's growing attentiveness to the potential of this medium to reach vast audiences. Indeed, French cinema attendance peaked during the late- 
1930s, with nearly three-quarters of Parisians regularly attending in 1939.65 As well as projecting France's imperial might, newsreels were also used to showcase defensive fortifications at home. A Pathé-Journal newsreel shown on 30 November 1938 reassured viewers that they could feel 'safe in their homes'. 66 The date of broadcast is salient, coinciding with the National Strike. The message was unambiguous, bringing into sharper focus the failure of the French left (at least its leadership) to defend their country. Although the emergent picture was contradictory - proclaiming France to be safe from attack whilst simultaneously suggesting that social unrest rendered France vulnerable 67 - it helped undermine the legitimacy of Daladier's far-left critics. A wedge was driven between the extremist leadership and the rank-and-file, most of the latter shying away from agitation and demonstrating a willingness to contribute to national defence. 68

In light of the Italian claims, imperial unity and strength featured prominently in newsreels. Daladier's January trip to France's Mediterranean possessions was widely reported, notably Éclair-Journal's 'Le voyage de M. Daladier en Corse, Tunisie, et Algérie'. Further officially-sanctioned films followed in the spring, celebrating French military might (e.g. La sortie de la Flotte en Méditerannée and Marine 1939) and imperial grandeur (L'homme de Niger, Brazza ou l'épopée du Congo, La chevauchée hérö̈que). ${ }^{9}$ Pathé's award-winning documentary 'Somme-nous défendus?' offered the French people further assurances of the country's military preparedness, and the public seemed to prefer these upbeat messages to the sombre portrayals of decadence and social fragmentation characterizing feature films like Le jour se lève and Le règle $d u$ jeu, both of which performed poorly at the box office. ${ }^{70}$ Into the spring and summer, Franco-British unity was also stressed repeatedly, newsreels lavishing attention on Lebrun's trip to London in April and revelling in the participation of British troops in the 14 juillet celebrations in Paris. ${ }^{71}$ 
Semi-official newsreels not only had an impact on French opinion but resonated overseas, notably in Britain. The French companies Pathé and Gaumont produced many of the newsreels shown in British cinemas, helping French authorities to project a more positive image of France in British picture houses. During the winter of 1938-9, Gaumont ran a series of films focusing on France, notably its military might and imperial prestige, including one commending the 'good sense of the French working men' for ensuring the failure of the General Strike. ${ }^{72}$ Daladier's Mediterranean trip was extensively covered, as was the visit of Monsieur and Madame Lebrun to London. The re-affirmation of the entente on 14 July was celebrated widely, Gaumont proclaiming the two democracies 'companions in glory, honour and determination'.73

By this juncture, the British government had already pledged to guarantee France against external aggression, and had even introduced - largely to assuage French anxieties - peacetime conscription. Reflecting on the recent evolution of French social cohesiveness, Phipps reported in early-March that 'the country is now more united to meet a menace from abroad than for many years past', having undergone a 'steady swing away from the extremism' that had prevailed in 1936. The majority of the people, he concluded, sought a 'moderate but strong Government, and a truce from social and political agitation'. ${ }^{74}$ Daladier's personal standing was already high and would rise further in light of his resolute response to the German seizure of Czechoslovakia on 15 March 1939. Although powerless to prevent Hitler's coup, Daladier used the radio to deliver a message of firmness and resolve. His speech of 29 March resonated nationally and internationally. French newspapers welcomed his firmness, Phipps informing London that Daladier's claim that France 'had never been so united' was entirely justified. 75

Daladier had, albeit belatedly, lived up to his reputation as a 'strong man', and his use of the airwaves has led one historian to label him ' $L$ 'homme de radio'. ${ }^{76} \mathrm{He}$ also demonstrated opportunism, exploiting the Prague coup to 
secure greater governmental powers (pleins pouvoirs) justified as essential for national defence. As the British embassy reported, his request for full powers was broadly welcomed by a public that was 'less concerned with party disputes than [with] firmness and leadership from the Government'. ${ }^{77}$ He continued to rally popular support for his policies via published and broadcast speeches. On 27 June, before the Chamber of Deputies, he reiterated French unity and determination to withstand external aggression. ${ }^{78}$ Daladier's firm language, noted Corbin, is 'welcomed in England' as evidence 'of the sacrifices being made' by the French people. ${ }^{79}$ His government's success in galvanising a previously fractured country did not go unrecognised at the time. As Lamoureux recalled, Daladier's popularity was extraordinarily high, having stabilised the government, reestablished order, improved the nation's finances, and adopted a firmer line against the Dictators. ${ }^{80}$ The Paris embassy largely concurred, suggesting that the severity of the international crisis had silenced 'all but the most irreconcilable critics', the majority of the French populace seeking a 'strong Government' rather than a 're-intensification of party quarrels'. ${ }^{81}$

In little over a year since becoming President of the Council, Daladier had made a concerted effort to use the media to harness support and reinvigorate the French nation. As Alexander Werth observed, Daladier 'took upon himself the task of preparing France ... both materially and psychologically' for war. In sparking this French 'revivalism', however, he occasionally assumed a 'dictatorial air'; Werth even suggested that there was a 'streak of Vichy-ism' to Daladier, and this is evident in his treatment of the media. ${ }^{82}$ On 4 February 1939, a decree law brought radio news broadcasts under the central control of the centre permanent de l'information générale. ${ }^{83}$ The printed press was a harder beast to tame, but here too Daladier exploited the severity of the external menace to justify increased state control. A series of decree-laws were passed in early-1939 giving the government greater powers to prohibit the publication and dissemination of journals suspected of being mouthpieces for foreign governments. The News 
Department of the British foreign office, commenting on Daladier's efforts to control the press, suggested in May 1939 that he 'has shown signs recently of increasingly dictatorial manners \& methods'. ${ }^{4}$ On 29 July, further measures were passed increasing government control of the radio and cinema, and even facilitating the creation of a propaganda ministry. ${ }^{85}$ In late-August, the Nazi-Soviet Pact gave Daladier the opportunity he craved to silence his most consistent and virulent critics, prohibiting publication of the Communist journals L'Humanité and Ce Soir.

When war came in September 1939, the British were confident that France was a worthwhile ally. This had not always been the case. For much of the 1930s the image of France emanating from the media (on both sides of the Channel) had sustained a contrary impression, of a nation divided domestically and utterly reliant on Britain internationally. But, as Michael Dockrill has argued, reservations about France that were commonplace in Britain in the mid-1930s were overcome by 1939.86 For John Herman, this owed much to the reports being furnished by ambassador Phipps; where he had portrayed a weak and pacifist France unready for war in September 1938 he evoked a resolute nation prepared for conflict less than a year later. ${ }^{87}$ To an extent, therefore, this article seeks to restore some agency to the French themselves in explaining the more favourable impressions of France now being harboured in Britain. Daladier's administration was proactive in creating more positive perceptions of France abroad, firstly taking steps to overcome social unrest and later by galvanising French opinion behind a foreign policy of firmness that London would subsequently ascribe to. France's ability to become more assertive within the FrancoBritish partnership owed much to a significant shift in media representations of that country, a shift that was, at least in part, cultivated intentionally.

\section{References}


Adamthwaite, Anthony. "Democracies, Dictatorships and Public Opinion: Government, Press and Opinion in Britain and in France in the Approach to Munich." In Opinion publique et politique extérieure en Europe, II: 1915-1940, actes du colloque de Rome, février 1981, 341-352. Rome: Publications de l'Ecole française de Rome, 1984.

Addisson, Paul. "Patriotism under Pressure: Lord Rothermere and British Foreign Policy." In The Politics of Reappraisal, 1918-1939, edited by Gillian Peele and Chris Cook, 189-208. London: Macmillan, 1975.

Albert, Pierre. "Le presse française de 1871 à 1940." In Histoire générale de la presse française, tome III: De 1871 à 1940, edited by Claude Bellanger, 135-622. Paris: Presses universitaires de France, 1972.

Bédarida, François. "La 'gouvernante anglaise'." In Edouard Daladier, chef de gouvernement: auril 1938 - septembre 1939, edited by René Rémond and Janice Bourdin, 228-240. Paris: Presses de la FNSP, 1977.

Bell, P.M.H. France \& Britain, 1900-1940: entente and estrangement. London: Longman, 1996.

Bell, Philip, and Ralph White. "Our Great Ally France, 1938-1940." InterUniversity History Film Consortium, Archive Series No. 4 (1986).

Bloch, Marc. L'étrange défaite: Témoignage écrit en 1940. Paris: Sociétés des Editions Franc-Tireur, 1946.

Cowans, Jon. "Fear and Loathing in Paris: The Reception of Opinion Polling in France, 1938-1977." Social Science History 26, no 1 (2002): 71-104.

Crémieux-Brilhac, Jean-Louis. Les Français de l'an 40, tome I: La Guerre, oui ou non? Paris: Gallimard, 1990.

Dell, Simon. The Image of the Popular Front: The Masses and the Media in Interwar France. Basingstoke: Palgrave Macmillan, 2007.

Delporte, Christian. Les journalistes en France, 1880-1950: Naissance et construction d'une profession. Paris: Seuil, 1999. 
Delporte, Christian and Fabrice d'Almeida. Histoire des médias en France de la Grande Guerre à nos jours. Paris: Éditions Flammarion, 2010.

Dockrill, Michael. British Establishment Perspectives on France, 1936-40. Basingstoke, 1999.

Dodd, Lindsey. "Are We Defended? Representations of War in Pre-War France." University of Sussex Journal of Contemporary History 12 (2008): 113.

Du Réau, Elisabeth. Édouard Daladier, 1884-1970. Paris: Fayard, 1993. Duroselle, Jean-Baptiste. La décadence, 1932-1939. Paris: Imprimerie Nationale, 1979.

Géraud, André [Pertinax]. Les Fossoyeurs: Défaite militaire de la France, armistice, contre-révolution. New York: Éditions de la Maison française, 1943. Harvey, John, ed. The Diplomatic Diaries of Sir Oliver Harvey, 1937-1940. London: John Harvey, 1970.

Herman, John. The Paris Embassy of Sir Eric Phipps: Anglo-French Relations and the Foreign Office, 1937-1939. Brighton, 1998.

Imlay, Talbot. “The Making of the Anglo-French Alliance, 1938-39." In AngloFrench Defence Relations Between the Wars, edited by Martin S. Alexander and William J. Philpott, 92-120. New York: Berghahn Books, 2002.

Jeanneney, Jean-Noël. Une histoire des médias: des origines à nos jours. Paris: Seuil, 2001.

Lacaze, Yvon. L'opinion publique française et la crise de Munich. Berne: Peter Lang, 1991.

Martin, Benjamin Franklin. Years of Plenty, Years of Want: France and the Legacy of the Great War. De Kalb, Il: NIU Press, 2013. 
Mayaffre, Damon. “Exalter l'Empire pour déserter l'Europe: le repli Impérial dans le discours munichois." Revue française d'histoire d'outre-mer 87, nos. 326-327 (2000): 273-286.

Méadel, Cécile. Histoire de la radio des années trente. Paris: Anthropos/INA, 1994.

Micaud, Charles. The French Right and Nazi Germany, 1933-1939: A Study of Public Opinion. Durham, NC: Duke University Press, 1943.

Perry, Matt. Memory of War in France, 1914-45: César Fauxbras, the Voice of the Lowly. Basingstoke: Palgrave Macmillan, 2011.

Self, Robert, ed. The Neville Chamberlain Diary Letters, Volume 4: The Downing Street Years, 1934-1940. Aldershot: Ashgate, 2005.

Seymour-Ure, Colin. The Political Impact of the Mass Media. London: Constable, 1974.

Tudesq, André-Jean. "L'utilisation gouvernementale de la radio." In Edouard Daladier, chef de gouvernement: avril 1938 - septembre 1939, edited by René Rémond and Janice Bourdin, 255-264. Paris: Presses de la FNSP, 1977.

Vidal, Georges. "Le Parti Communiste français et la défense nationale (septembre 1937 - septembre 1939)." Revue Historique 630 (2004): 333-369.

Weber, Eugen. The Hollow Years: France in the 1930s. New York: Norton, 1996.

Werth, Alexander. France in Ferment, 1933-1935. London: Jarrolds, 1935 [1934].

Werth, Alexander. The Twilight of France. New York: Howard Fertig, 1966 [1942].

Young, Robert. France and the Origins of the Second World War.

Basingstoke: Macmillan, 1996. 


\section{Notes}

${ }^{1}$ Bell, France \& Britain, 253.

2 The decadence school is most closely associated with Duroselle's La décadence, but has its roots in Marc Bloch's L'étrange défaite and the volume written by the journalist André Géraud ('Pertinax'), Les Fossoyeurs. See also Weber, The Hollow Years.

3 Bédarida, "La 'gouvernante anglaise", 228-40.

${ }^{4}$ For example, Imlay, "The Making of the Anglo-French Alliance", 92-120 and Young, France and the Origins of the Second World War.

${ }^{5}$ Herman, The Paris Embassy of Sir Eric Phipps, 24.

${ }^{6}$ Werth, preface to the 1935 edition of France in Ferment, 7.

7 This narrow focus caused concern in the Foreign Office during the Sudeten Crisis in September 1938. Oliver Harvey, suspecting ambassador Phipps' of presenting one-sided appraisals of French opinion, asked that consular reports to be sent directly to London, unadulterated by the Paris embassy, to reflect more accurately the state of French opinion. Harvey (ed.). Diplomatic Diaries of Oliver Harvey, 27 September 1938, 124.

8 Seymour-Ure, The Political Impact of Mass Media, 77.

9 The National Archives [TNA], FO 371//20685/C2990/18/17: Lloyd Thomas to FO, 20 April 1937.

10 Albert, "La presse française de 1871 à 1940", 526.

11 Ibid.

12 Perry, Memory of War in France, 101.

13 Dell, The Image of the Popular Front, 29-30.

14 Albert, "La presse française de 1871 à 1940", 511. Circulation figures apply to March 1939. For a more recent account of the French press, and the role of French journalists in particular, see Delporte, Les journalistes en France. For more general overviews of the French media, see Jeanneney, Une histoire des médias, and Delporte and d'Almeida, Histoire des médias en France.

15 Admathwaite, "Democracies, Dictatorships and Public Opinion", 347.

16 Perry, Memory of War in France, 101; Herman, The Paris Embassy, 24.

17 Cowans, "Fear and Loathing in Paris", 75.

18 For more on politicization of French radio see Jeanneney, Une histoire des médias and Méadel, Histoire de la radio.

19 Addisson, "Patriotism under Pressure", 191-2.

${ }^{20}$ Léon Merklen, 'L'heure de la prière', La Croix, 11 March 1936.

${ }^{21}$ Micaud, The French Right, 85-106. 
22 TNA, FO 371/19897/C2314/4/18: Clerk to Eden, 25 March 1936.

${ }^{23}$ Documents Diplomatiques Français [DDF], 2e Série, Tome III: No. 280: Corbin to Delbos, 23 September 1936.

24 TNA, FO 371/19857/4465/1/17: Phipps to Wigram, 18 June 1936.

25 'Commentaires étrangers sur les élections françaises', Le Petit Parisien, 5 May 1936.

${ }^{26}$ Gallus, 'Et maintenant?', L'Intransigeant, 5 May 1936.

${ }^{27}$ Léon Daudet, 'Victorieux sur une planche pourrie', L'Action Française, 8 May 1936.

${ }^{28}$ M. le Provost de Launay, 'Un appel aux anciens combattants patriotes', Le Figaro, 9 July 1936.

${ }^{29}$ Herman, The Paris Embassy, p. 28.

30 TNA, FO 371/19856/C4040/1/17: Clerk telegram, 4 June 1936.

31 TNA, FO 371/19857/C4349/1/17: Lloyd Thomas to Vansittart, 11 June 1936.

32 TNA, FO 371/19857/C4383/1/17: Clerk telegram, 17 June 1936.

33 La bibliothèque de documentation internationale contemporaine [BDIC], Nanterre:

Papiers Lucien Lamoureux, 'Souvenirs politiques', Mfm 31.

${ }^{34}$ Archives Nationales [AN], Fonds Kayser, 465 AP/7: 2 KA 6, Dr. 2: Speech by Jacques

Kayser (in the name of the Radical-Socialist Party) at the Place de la Nation, 25 June 1937.

35 The Evening Standard, editorial, 11 December 1936.

${ }^{36} D D F, 2$ e Série, Tome IV: No. 302: Corbin to Delbos, 14 January 1937.

37 TNA, FO 371/20696/C1155/1127/17: Clerk to the Foreign Office, 9 February 1937.

38 TNA, FO 371/20687/C8134/18/17: Phipps to Eden, 25 November 1937.

39 Gabriel Péri, in L'Humanité, 16 January 1938. Émile Buré, in L'Ordre (16-17 January 1938), was equally critical of perceived British meddling in French domestic politics, though less strident in his rhetoric.

40 Chamberlain to Hilda, 13 March 1938, cited in Self (ed.), Neville Chamberlain Diary Letters, 305.

${ }^{41}$ Archives d'histoire contemporaine, Centre d'histoire de Sciences Po [CHSP], Fonds Roger Genébrier, GE 6: Daladier radio broadcast (transcript), 21 August 1939.

42 CHSP, Fonds Roger Genébrier, GE 12: Churchill to Daladier, 14 April 1938.

${ }^{43}$ See, for example, Halifax's comments to Phipps in a letter of 13 April 1938 (TNA, FO $800 / 311)$.

${ }^{44}$ Harvey (ed.). Diplomatic Diaries of Oliver Harvey, 19 - 24 July 1938, 166. For more on this see Bell, France \& Britain, 218.

45 TNA, FO 371/21600/C12854/55/17: Phipps report on events in France during the third quarter of 1938, 22 October 1938.

46 TNA, CAB 21/554/C3388/55/17: Phipps to Halifax, 24 April 1938.

47 TNA, FO 371/21767/C11380/4770/18: Phipps to Halifax, 1 October 1938; TNA, FO 371/21767/C11502/4770/18: Phipps to Halifax, 3 October 1938.

48 AN, Fonds Daladier, 496 AP/10, 2 DA 3, dr. 4. 
49 TNA, FO 800/311: Phipps to Halifax, 24 October 1938.

50 TNA, FO 371/C13323/1083/17: Phipps telegram, 2 November 1938; TNA, FO

371/21622/C13513/13363/17: Phipps telegram, 6 November 1938.

51 TNA, FO 371/21613/C13362/1083/17: Phipps telegram, 3 November 1938.

52 CHSP, Fonds Roger Genébrier, GE 6: Daladier radio broadcast (transcript), 12 November 1938.

53 AN, Fonds Daladier, 496 AP/10, 2 DA 3, dr. 6 (original emphasis).

${ }^{54}$ AN, Fonds Daladier, 496 AP/11, 2 DA 4, dr.1: Président du Conseil: Service de presse et d'information, 28 November 1938.

55 Ministère des Affaires Étrangères [MAE], Série Z: Europe, 1919-1940: No. 291: Corbin to Bonnet, 26 November 1938.

56 TNA, FO, 371/21602/C14704/92/17: Phipps to Halifax, 28 November 1938.

57 TNA, FO 371/21600/C14022/55/17: Peake memorandum, 12 November 1938.

58 TNA, FO 371/21600/C14025/55/17: Barclay minute, 18 November 1938.

59 TNA, FO 371/22428/R9809: Phipps telegram, 9 December 1938. For a general appraisal by Phipps of French reactions to the Italian claims, see his telegram of 19 December 1938 (TNA, FO 371/22429/R10098).

60 BDIC, Mfm. 31: Lamoureux, 'Souvenirs politiques'.

61 TNA, FO 371/ 22429/R10272: D’Ormesson to Lord Winterton, 18 December 1938

(forwarded to Caccia in the Foreign Office on 22 December).

62 Martin, Years of Plenty, p. 182.

63 Mayaffre, "Exalter l'Empire pour déserter l'Europe", 285.

64 Phipps to Halifax, 10 November 1938: TNA, FO 371/21603/C13846/101/17.

65 Benteli, Jay and Jeancolas, "Le cinéma français", 28.

66 Dodd, “Are We Defended?" 4.

67 Ibid., p. 5.

68 Georges Vidal, "Le Parti Communiste français et la défense nationale”, 333-69.

69 Benteli, Jay and Jeancolas, "Le cinéma français", 38-9.

70 Dodd, “Are We Defended?" 1.

${ }^{71}$ Benteli, Jay and Jeancolas, "Le cinéma français", 39-40. The emphasis on the Entente-

Cordiale during the Bastille Day celebrations was echoed throughout the printed press invariably accompanied by a plethora of photographs. See, for example, Le Petit Parisien, 15 July 1939, and especially Paris-Soir, 15 July 1939.

72 Bell and White, 'Our Great Ally France', 14-15.

73 Bell and White, 'Our Great Ally France', 22.

74 TNA, FO 371/22909/C3070/25/17: Phipps to Halifax, 13 March 1939.

75 TNA, FO 371/22909/C5013/25/17: Phipps to Halifax, 6 April 1939.

76 Crémieux-Brilhac, Les Français de l'an 40, 297; du Réau, Édouard Daladier, 319.

77 TNA, FO 371/22909/C3439/25/17: Campbell telegram, 19 March 1939. 
78 Journal Officiel de la République française [JO]: Débats parlementaires, Chambre des députés: Daladier speech, 2e séance, 27 June 1938, 1872-1873.

79 MAE, Série Z: Europe, 1919-1940, no. 283: Corbin to Bonnet, 28 June 1939.

80 BDIC, Mfm. 31: Lamoureux, 'Souvenirs politiques'.

81 TNA, FO 371/22909/C9799/25/17: Phipps report on internal events in France during the second quarter of 1939, 11 July 1939; TNA, FO 371/22910/C10889/25/17: Campbell telegram, 3 August 1939.

82 Werth, Twilight of France, 345.

83 JO: Lois et décrets, 8 February 1939, 1770. See also Tudesq, "L'utilisation gouvernemantale de la radio", 255-64.

84 TNA, FO 371/22934/C6896/1314/17: New Department minute, 8 May 1939.

85 JO: Lois et décrets, 7 May 1939, 5774; JO: Lois et décrets, 29 July 1939, 9626. See also Amaury, De l'information et de la propagande d'État.

86 Dockrill, British Establishment Perspectives, 161.

${ }^{87}$ Herman, The Paris Embassy, 182. 